\title{
O SUICÍDIO COMO QUESTÃO: MELANCOLIA E PASSAGEM AO ATO ${ }^{1}$
}

SUICIDE AS A QUESTION: MELANCHOLY AND PASSAGE TO THE ACT

EL SUICIDIO COMO CUESTIÓN: MELANCOLÍA E PASAJE A LO ACTO

Marcos Vinicius Brunhari*

Vinicius Anciães Darriba**

\section{Resumo}

O artigo toma a questão do suicídio na obra de Freud como um problema de pesquisa que interroga certos pontos de sua metapsicologia: a possibilidade de uma tendência à autodestruição, o papel do eu e, finalmente, a dimensão do objeto que estaria implicada. É em relaçáo a este último, em particular a seu estatuto na articulação que Freud propóe entre suicídio e melancolia, que o trabalho de Lacan em torno do objeto $a$, associado à passagem ao ato e à melancolia no Seminário, livro 10 - A angústia (1962-1963/2005), figura, no artigo, como um acréscimo à investigação iniciada por Freud. Essa referência lacaniana permitirá destacar a presença fulgurante do objeto $a$ no momento da passagem ao ato suicida, estabelecendo uma articulação com a identificação melancólica descrita por Freud em seu "Luto e melancolia" (1917 [1915]/1969). A essa identificação absoluta ao objeto em questão é correlata a ausência de um sujeito e a ruptura mais radical em relação ao Outro.

Palavras-chave: suicídio; passagem ao ato; melancolia; Freud; Lacan.

\section{Abstract}

This article approaches the suicide issue within Freud's works as a research problem which questions certain points of his metapsychology: the possibility of a tendency to auto-destruction, the ego role and, finally, the object dimension which would be implicit. In regards to this last one, in special to its statute in the

\footnotetext{
* Universidade de São Paulo, São Paulo, SP, Brasil.

** Universidade do Estado do Rio de Janeiro, Rio de Janeiro, RJ, Brasil.
} 
articulation which Freud proposes between suicide and melancholy, that Lacan's works about object "a", related to the passage to the act as well as to the melancholy within "Seminar, book 10 - The anguish" (1962-1963/2005) figures, in this article, as an addition to the investigation initiated by Freud. This Lacanian reference will allow to highlight the vivid presence of object "a" at the moment of the passage to the suicide act, establishing a link to the melancholy identification described by Freud in his text "Mourning and melancholy" (1917 [1915]/1969). Towards this absolute identification to the object in matter, it is correlative to an absence of a subject and a more radical rupture in regards to the Other.

Keywords: suicide; passage to the act; melancholy; Freud; Lacan.

\section{Resumen}

En este artículo se aborda el tema del suicidio en las obras de Freud como un problema de investigación que cuestiona ciertos puntos de su metapsicología: la posibilidad de una tendencia a la auto-destrucción, el papel del yo y, por último, la dimensión del objeto que estaría implícita. En referencia a esta última, en especial a su estatuto en la articulación que Freud propone entre el suicidio y la melancolía, que el trabajo de Lacan sobre el objeto "a”, relacionado con el pasaje al acto y la melancolía en Seminario, libro 10 - La angustia (1962-1963/2005), figura, en el artículo, como una adición a la investigación iniciada por Freud. Esta referencia lacaniana permitirá destacar la presencia viva do objeto "a” en el momento de la pasaje al acto suicida, estableciendo un vínculo con la identificación melancólica descrita por Freud en su texto "Duelo y melancolía” (1917 [1915]/1969). Hacia esta identificación absoluta al objeto en cuestión, es correlativa a la ausencia de un sujeto y una ruptura más radical con respecto al Otro.

Palabras clave: suicidio; pasaje al acto; melancolía; Freud, Lacan.

Neste artigo, pretende-se examinar as consideraçóes de Freud a respeito do suicídio, articulando em seguida, a partir de Lacan, o suicídio nos termos da queda do objeto $a$. As principais referências serão o trabalho "Luto e melancolia" (1917 [1915]/1969), no qual Freud tece os mais relevantes apontamentos sobre a melancolia e sua articulação com o suicídio, e o Seminário, livro 10 - a angústia (1962-1963/2005), trabalho em que Lacan propóe a passagem ao ato, incluído o ato suicida, desde a identificaçáo absoluta do sujeito ao objeto $a$.

$\mathrm{O}$ percurso que será traçado na obra de Freud na primeira parte desse artigo começa pelas considerações iniciais do autor, segundo as quais o suicídio pertence à mesma categoria dos atos falhos e lapsos. Nesse início, Freud refere-se 
a uma tendência à autodestruição implícita nos ferimentos autoinfligidos e nos suicídios concluídos ou não. Essa tendência terá proeminência na obra do autor ao ser referida como sadismo que retorna ao eu e, posteriormente, como cultura pura de pulsão de morte.

Associados a tal fator proeminente nas consideraçóes de Freud sobre o suicídio estão a identificação narcísica ao objeto e o processo melancólico. Pretende-se evidenciar, no artigo, como a via da identificação narcísica a determinado objeto abre a melancolia como campo no qual Freud articula a questão do suicídio. Será desde a articulação freudiana entre melancolia e suicídio que este poderá ser examinado segundo as proposiçóes de Lacan sobre a passagem ao ato. A identificação melancólica descrita por Freud será aproximada da identificação absoluta ao objeto $a$, condição primeira para a passagem ao ato. Assim, a partir das consideraçóes de Lacan, será possível retomar a dimensão de ato do suicídio e localizá-lo nos termos da queda do objeto $a$.

\section{Melancolia e suicídio: uma articulação freudiana}

Dentre as primeiras referências de Freud ao suicídio, em "Sobre a psicopatologia da vida cotidiana" (1901/1969), ele reserva um capítulo para descrever os "equívocos na ação [Vergreifen]" (Freud, 1901/1969, p. 167). Segundo o autor, basta um passo, a partir dos lapsos na fala, para que se considerem os equívocos da ação como formados da mesma maneira que os lapsos. Essa formação compartilhada se observa desde o efeito falho, um desvio do que era intencionado, como característica fundamental. Dentro dessa categoria de equívocos na ação, Freud enumera situaçóes em que atos apontam para determinaçóes inconscientes escamoteadas sob equívocos e erros. São pequenos acidentes ou o uso inadequado de objetos e, também, quedas, escorregóes, passos em falso e ferimentos autoinfligidos. Quanto aos ferimentos autoinfligidos, Freud afirma que "nunca se pode excluir o suicídio como um possível desfecho do conflito psíquico” (1901/1969, p. 181).

A proposta de Freud é de dispor as tentativas ou conclusóes de suicídio como reveladoras de uma intenção inconsciente que pode estar mascarada por um acidente casual. Dessa forma, ele argumenta que uma tendência à autodestruição está presente em certa medida e que "os ferimentos autoinfligidos são, em geral, um compromisso entre essa pulsão e as forças que ainda se opóem a ela" (Freud, 1901/1969, p. 183). Freud indica a presença de uma pulsão que impele à autodestruição, o que pode ser reconhecido como um germe da pulsão 
de morte, na base das tentativas ou conclusões suicidas de ordem consciente ou inconsciente. Segundo o autor, duas forças se opóem e os ferimentos autoinfligidos surgem a partir da tendência à autodestruição que supera as forças que se lhe opõem. Esse prenúncio da desfusão pode ser antevisto nas consideraçóes de Freud (1901/1969) sobre o suicídio como pertencente à categoria de equívocos na ação.

Vale notar, então, que o exame do problema do suicídio nos termos acima antecipa a conceituação por Freud de uma pulsão de autodestruição, visto tratar-se aqui de uma reflexão efetuada já em 1901. Essa interrogação acerca da possibilidade da autodestruição é importante para aquilo que se segue na obra de Freud a respeito do suicídio. Em uma conferência intitulada "Contribuiçóes para uma discussão acerca do suicídio” (1910/1969), ele aborda o suicídio como algo obscuro e de causas misteriosas. Diante da pulsão de vida subjugada, Freud questiona se a renúncia à autopreservação teria como base motivos do próprio eu. Charliac (2002) atenta para esse ponto da reflexão de Freud ao observar que há, nessa passagem de 1910, uma exposição do problema do suicídio a partir de duas propostas metapsicológicas não excludentes entre si: "De um lado, a renúncia do eu à vida poderia ser provocada por uma decepção da libido devido a causas externas; de outro lado, a renúncia poderia provir de causas internas, de motivos próprios ao eu" (Freud, 1910/1969, p. 209). O deslocamento da investigação para o campo do eu acarreta, assim, a reformulaçáo da pergunta inicial sobre uma tendência à autodestruição para uma nova pergunta concernente a uma renúncia à autopreservação por parte do eu.

Freud afirma não ter subsídios para responder à questão, contudo não deixa de propor um encaminhamento. Segundo ele, é possível "tomar como ponto de partida a condição de melancolia, que nos é tão familiar clinicamente, e uma comparação entre ela e o afeto do luto" (Freud, 1910/1969, p. 244). Estabelecido o binômio luto e melancolia, que perdurará ao longo da obra de Freud, o suicídio tem a melancolia como referência, na medida em que a interrogaçáo passa a inquirir uma renúncia por parte do eu. A formação binomial luto e melancolia é estabelecida por Freud (1910/1969) como condição para que se avance na temática do suicídio. Deve-se sublinhar que, nesse segundo tempo das consideraçóes sobre o suicídio, fica claro tratar-se de um problema de pesquisa a que Freud se dedica. Além disso, a interrogação sobre o papel do eu na autodestruição estabelece, para o autor, a melancolia, em contraposição ao luto, como o terreno em que tal pesquisa será desenvolvida.

Ainda em "Contribuições para uma discussão acerca do suicídio" (1910/1969), Freud afirma não haver resposta possível para a questão sobre como seria possível o eu renunciar à autopreservação. Ele atribui a impossibilidade de res- 
posta à ausência de meios para tanto e, como vimos, indica o estudo da melancolia em sua correlação com o luto como caminho. Destacamos novamente que o suicídio se revela uma questão para Freud e que o terreno da melancolia é o que está a seu alcance, na medida em que a renúncia à autopreservação e o desapego à vida são características articuladoras do suicídio com o quadro melancólico. Será em "Luto e melancolia” (1917 [1915]/1969) que Freud retomará tal articulação, propondo abandonar qualquer reivindicação à universalização daquilo que desenvolverá acerca da melancolia, uma vez que esta assume várias formas de definição mesmo para a psiquiatria descritiva. Dispóe-se a abordar apenas os casos em que a natureza psicogênica é indiscutível. O trajeto que seguimos até aqui faz ver o quanto o trabalho reflexivo realizado nesse escrito já vinha sendo, desde antes, propulsado pelas dificuldades em elucidar o que estaria em jogo na problemática do suicídio.

A correlação entre luto e melancolia é justificada por Freud na medida em que o quadro geral dessas duas condiçóes refere uma perda. Entretanto, enquanto no luto há a "reação à perda de um ente querido, como os pais, a liberdade ou o ideal de alguém, e assim por diante" (Freud, 1917 [1915]/1969, p. 249), na melancolia há "uma disposição patológica" (Freud, 1917 [1915]/1969, p. 249). O que se apresenta na melancolia é uma diminuição, um escoamento da autoestima. Portanto, é algo que se afigura no eu e que é exclusivo da melancolia, não presente no luto.

O desânimo, o desinteresse pelo mundo, a incapacidade de amar, a inibição e a diminuição da autoestima chegam ao ponto de encontrarem expressão na "autorrecriminação e autoenvilecimento, culminando numa expectativa delirante de punição" (Freud, 1917 [1915]/1969, p. 250). Esse conjunto, que pode até mesmo revelar uma expectativa delirante de punição e que expressa um caráter de escoamento do eu, sustenta-se sobre uma perda. Assim, Freud (1917 [1915]/1969, p. 251) aponta o processo melancólico a partir da perda de um "objeto amado", ou melhor, "uma perda de natureza mais ideal" da qual não se tem notícias, pois não se conhece o que foi perdido. Essa perda está retirada da consciência.

Segundo Freud, não se conhece o que foi perdido e que está "absorvendo tâo completamente" (1917 [1915]/1969, p. 251) o eu, tornando-o vazio e empobrecido (Ichverarmung), ou autoempobrecido, como revela o termo em alemão, caído na miséria. Freud assinala que é o próprio paciente quem envilece, torna vil e abjeto o eu. É o paciente quem "estende sua autocrítica até o passado, declarando que nunca foi melhor” (Freud, 1917 [1915]/1969, p. 252), constituindo um delírio de insignificância moral, recusando-se a comer e a dormir em um processo no qual é suprimido aquilo que "compele todo ser vivo a se apegar à vida" (Freud, 1917 [1915]/1969, p. 252). 
Freud se debruça sobre esse retorno ao eu, dizendo ser improdutivo contradizer o paciente em sua certeza sobre tal acusação. Afirma que, de alguma forma, há nisto razão. É nesse processo em que o paciente encontra-se desinteressado e "incapaz de amor" (Freud, 1917 [1915]/1969, p. 252) que se verificam as acusaçôes que se justificam, segundo Freud, por uma visão mais penetrante da realidade e pela proximidade a uma verdade, o que leva ao adoecimento. $\mathrm{O}$ enfoque não está em saber se a autodifamação do eu é correta ou não, o fato está em que isto tem sua razão. Ao considerar essa razão, Freud pôde observar que a perda do amor-próprio do eu denota a perda relativa ao eu.

A diminuição do amor-próprio, da autoestima, é a mais marcante das características da melancolia. É a partir dela que Freud observa que as injúrias que o paciente dirige a si podem se ajustar a outrem, "a alguém que o paciente ama, amou ou deveria amar” (Freud, 1917 [1915]/1969, p. 254). Portanto, as injúrias dirigidas a um objeto de amor são deslocadas contra o eu. Esse deslocamento contra o eu se baseia na ambivalência da relação amorosa com o objeto. É nisso que se fundamentam os lamentos e queixas (Klagen) que não passam de acusaçóes (Anklagen). Freud faz um jogo com as palavras Klagen e Anklagen permitindo uma compreensão de um eu perseguidor, ativo em sua ação de dar queixas de si próprio. Identifica-se aqui o prenúncio do conceito de supereu e de sua função no processo melancólico, o que será determinante para a elucidação da problemática do suicídio. Em contrapartida, é preciso considerar ter sido esta última - ao ensejar a pergunta sobre o papel do eu na autodestruição e a articulação com a melancolia - que fez vislumbrar a possibilidade de uma partição no eu, a qual condicionou o progresso da metapsicologia freudiana.

Segundo o autor, na melancolia, em uma relação objetal particular, há um enlaçamento que é destruído. Ele afirma não ser o resultado disto um processo normal de desligamento do objeto no qual há um deslocamento para outro objeto; há sim um recolhimento da libido ao eu. Nesse recolhimento da libido, estabelece-se uma identificação do eu com o objeto que se foi: "assim a sombra do objeto caiu sobre o ego" (Freud, 1917 [1915]/1969, p. 254). Desde entâo, pode o eu ser julgado como o objeto perdido por uma instância crítica. É assim que a perda do objeto se transforma em uma perda do eu, levando Freud a reconhecer haver aí uma forte fixação no objeto e, concomitantemente, uma fraca aderência do investimento depositado. Diante disso, aponta a base narcísica sobre a qual é feita a escolha objetal. Perante certo obstáculo, o investimento de carga depositado no objeto regrediria ao narcisismo, não renunciando à relação amorosa. $\mathrm{O}$ amor depositado no objeto seria substituído pela identificaçáo narcísica. 
O investimento objetal tem, após sua ruptura, um duplo destino: uma parte volta-se por via identificatória e outra sob a forma de sadismo. Freud reconhece a importância desse sadismo no processo melancólico, sendo ele justamente o que permite pensar o suicídio na melancolia: "é exclusivamente esse sadismo que soluciona o enigma da tendência ao suicídio, que torna a melancolia tâo interessante - e táo perigosa" (Freud, 1917 [1915]/1969, p. 257). Segundo o autor, a tendência ao suicídio parecia inexplicável na medida em que, anteriormente, se considerava o estado primitivo da vida pulsional ser um grande amor do eu por si mesmo e o medo surgido diante de uma ameaça à vida ser correspondente a uma quantidade de libido narcísica liberada. Diante desses dois pontos, seria impossível compreender que o eu, táo preso e amoroso de si, atentasse contra si próprio. Sobre esse processo de autotortura promovido pelo eu, Lambotte (2000, p. 72) afirma que "o melancólico se esmera em matar o que o estorva na ignorância em que ele se encontra da natureza de seu adversário". Esse sadismo que se dirige ao eu subjugado ao objeto é, então, um elemento essencial às consideraçóes de Freud sobre o suicídio. É ao conceber o retorno do sadismo ao eu que Freud pôde sustentar a identificação ao objeto contra o qual atenta o eu em sua ignorância que o torna vítima e algoz concomitantemente:

A análise da melancolia mostra agora que o ego só pode se matar se, devido ao retorno da catexia objetal, puder tratar a si mesmo como objeto - se for capaz de dirigir contra si mesmo a hostilidade relacionada a um objeto, e que representa a reação original do ego para com objetos do mundo externo (Freud, 1917 [1915]/1969, p. 257).

Quando a catexia se desliga do objeto e retorna ao eu, há, na melancolia, uma identificação ao objeto e, desde então, com a volta da catexia objetal, o eu trata-se como se fosse o objeto perdido. Nesse processo de se tratar como objeto, o eu dirige para si a hostilidade que é original da relação com aquele. É assim que "ele [o objeto], não obstante, se revelou mais poderoso do que o próprio ego" (Freud, 1917 [1915]/1969, p. 257). O objeto triunfa sobre o eu e isso se dá pela via do amor e do ódio que sustentavam a relação.

Sobre o triunfo do objeto como via para o suicídio, Quinet (2006, p. 207) destaca um deslocamento, visto que "não é mais pelo narcisismo, e sim pela própria teoria pulsional e a identificação do sujeito ao objeto que ele [Freud] passa a explicar o suicídio na melancolia”. O modo como Freud dispóe sobre a questão do suicídio passa a incluir a dimensão do objeto; ou seja, o eu apenas atenta contra si na medida em que ataca um objeto em si. Desse modo, a pesquisa acerca 
do problema do suicídio, que já se desdobrara, em Freud, da interrogação sobre o que possibilita a autodestruição ao aprofundamento do que a condiciona desde a instância do eu, valendo-se do paradigma da melancolia, avança agora para a problemática do objeto.

Freud, além disso, propõe ainda um exame tópico da melancolia para considerar em quais sistemas psíquicos seu processo se desenrola. $\mathrm{O}$ autor inicia tal reflexáo sobre a tópica afirmando que a representação mental inconsciente (da coisa) "do objeto foi abandonada pela libido" (Freud, 1917 [1915]/1969, p. 261). Como já observado, a ambivalência seria base para o que se processa na melancolia. Segundo Freud, em relação ao objeto há uma luta entre amor e ódio, e "a localização dessas lutas só pode ser atribuída ao sistema Ics., a região dos traços de memória de coisas (em contraste com a catexia da palavra)" (Freud, 1917 [1915]/1969, p. 261). Topograficamente, portanto, o processo da melancolia, que compreende a ambivalência em sua fundamentação, ocorre em um lugar diferente do das palavras e, deste lugar, o caminho para a consciência é barrado para o melancólico. No embate entre amor e ódio, o ódio avança e desliga o objeto, enquanto que, "refugiando-se no ego, o amor escapa à extinção" (Freud, 1917 [1915]/1969, p. 262). É assim que, após o abandono do objeto e a consequente identificação narcísica, o conflito passa a ser representado para a consciência como uma tensão entre o eu e o agente crítico, o qual, como observamos, será designado, em 1923, por supereu. Este figurará no bojo de uma concepção do eu como formado a partir de identificaçóes que tomam o lugar de investimentos abandonadas pelo isso: "a primeira dessas identificaçóes sempre se comporta como uma instância especial no ego e dele se mantém à parte sob a forma de um superego" (Freud, 1923/1969, p. 61).

A manifestação do supereu acarreta o sentimento de culpa tanto na melancolia quanto na neurose obsessiva. Contudo, o melancólico admite a culpa e se submete ao castigo, náo havendo objeção por parte do eu. É nessa postura, tipicamente melancólica, que se sustentam as lamentaçóes. O sadismo que se dirige ao eu é conteúdo do supereu, criando assim uma "cultura pura do instinto de morte e, de fato, ela com bastante frequência obtém êxito em impulsionar o ego à morte, se aquele não afasta o seu tirano a tempo, através da mudança para a mania” (Freud, 1923/1969, p. 66). A implicação do supereu na análise do suicídio é fundamental, visto ser desde essa instância concebível que o eu assuma a culpa e se castigue, identificado ao objeto.

O percurso da pesquisa freudiana sobre o suicídio, iniciado com o vislumbre de uma tendência à autodestruição que o caracterizaria dentre outros atos, avançou, tomando a melancolia como via de resposta. Esta indica o sadismo e a identifi- 
cação narcísica como elementos de um processo no qual a sombra de um objeto se sobrepóe ao eu. Subjugado ao triunfo do objeto sobre si, o eu se castiga como outrem e, apenas dessa forma, é possível matar-se, matando o objeto com o qual se identificou. $\mathrm{O}$ processo de automortificação do eu melancólico é situado por Freud como relativo à perda que ocorreu no eu. Não desprovido de razão pelo autor, o eu melancólico mostra que as injúrias são dirigidas a um objeto que, por certo motivo, o habita. É então que a sombra que recobre o eu se fundamenta na identificação narcísica em que o retorno sobre o eu tem o caminho marcado. É importante destacar que este processo se estabelece, segundo afirma Freud (1915 [1917]/1969), fora do âmbito das palavras. Assim, a prevalência do que está fora do âmbito das palavras sobre o eu melancólico acresce-se a uma elaboração freudiana que tem na identificação narcísica o eixo essencial para a consideração do suicídio na melancolia.

A trajetória do tema do suicídio na obra de Freud situa a identificação narcísica ao objeto como ponto chave desde o qual, na melancolia, todo o processo de autodestruição se desenrolaria. Contudo, em acréscimo à articulação de um objeto que triunfa sobre o eu, cabe reinterrogar a dimensão de ato do suicídio, que vimos ser considerada por Freud em 1901. Essa dimensão de ato implicada no suicídio não chega a ser explorada no exame da problemática melancólica, restando como uma indicação pontuada por Freud ainda no primeiro tempo de sua investigação.

Ao indicar a delimitação freudiana do suicídio à melancolia, na medida em que este ponto de vista marca uma identificação radical ao objeto, Charliac (2002, p. 210) afirma que "esta ideia foi tomada por Lacan em seu Seminário A angústia desde onde ele avança ao propor que a passagem ao ato suicida, em particular na melancolia, encontra seu correlato em um deixar-se cair do sujeito". Assim, a identificação absoluta ao objeto encontrará, a partir de Lacan (19621963/2005), uma aproximação com o deixar-se cair evidenciado pelo ato suicida. É com o intuito de avançar neste ponto, que recorremos, na sequência, aos apontamentos de Lacan (1962-1963/2005) acerca do deixar-se cair e da passagem ao ato suicida na melancolia. Para tal, faz-se necessário um breve percurso sobre os elementos destacados pelo autor em seu seminário de 1962-1963.

\section{Angústia, objeto $a$ e passagem ao ato}

Mantendo laços estreitos com seus seminários anteriores, Lacan, no Seminário, livro 10: a angústia (1962-1963/2005), inicia afirmando que a angústia será o tema daquele ano. A partir desse tema serão desenvolvidos os apontamentos e as consideraçóes do autor sobre a passagem ao ato. 
Sobre a angústia, Lacan (1962-1963/2005, p. 23) afirma: "para introduzi-la, direi que ela é um afeto”. A proposição da angústia como afeto a coloca em relação estrutural ao sujeito e a caracteriza como não passível ao recalque. É dessa forma que a angústia encontra-se à deriva e fora da rede significante. Estar fora da rede significante permite ao autor expressar-se de maneira gráfica, por meio de um quadro em que os termos acting out e passagem ao ato são posicionados em relação à angústia. $\mathrm{O}$ objeto $a$ apresenta-se, no que se segue, como possibilidade de aferência a ambos os termos. Lacan (1962-1963/2005, p. 36) situa esse objeto da seguinte maneira:

Em relaçáo ao Outro, o sujeito dependente desse Outro inscreve-se como um cociente. É marcado pelo traço unário do significante no campo do Outro. Não é por isso, se assim posso dizer, que ele corta o Outro em rodelas. Há, no sentido da divisão, um resto, um resíduo. Esse resto, esse Outro derradeiro, esse irracional, essa prova e garantia única, afinal, da alteridade do Outro, é o $a$.

O sujeito se inscreve no campo do Outro e disso resta o objeto $a$, o qual não pode ser sintetizado. A divisão não resulta inteira, há resto. E exatamente esse resto é o que garante o Outro. Eis a anterioridade garantida pelo resto da divisão e pela assertiva de que o sujeito é dependente do Outro.

A presença do objeto $a$, com a divisão do sujeito no campo do Outro, é salientada por Lacan (1962-1963/2005) com a distinção entre a cena e o mundo. A cena, assim como retoma da obra de Freud, Lacan (Lacan, 1962-1963/2005, p. 42) indica tratar-se de uma dimensão na qual as coisas, mesmo aquelas do mundo, vêm a se dizer. Enquanto que o mundo existe, "todas as coisas do mundo vêm colocar-se em cena segundo as leis do significante" (Lacan, 1962-1963/2005, p. 42-43). É justamente por estar fora da rede significante que a angústia indica a presença do objeto $a$ e se substancializa como "aquilo que não engana" (Lacan, 1962-1963/2005, p. 88).

Ao delimitar que a angústia não engana, ao contrário do significante, Lacan (1962-1963/2005, p. 88) aponta que ela corresponde à certeza e que "talvez seja da angústia que a ação retira sua certeza”. As referências ao que da angústia não engana, ao que escapa à rede, ao que no mundo não é dito revelam a certeza da angústia e indicam a ação, mais especificamente o acting out e a passagem ao ato. Harari (1997, p. 79) define que "tanto o acting out como a passagem ao ato indicam operaçóes por meio das quais o sujeito se relaciona com o objeto $a$ ". A certeza que se enxerta no ato tem seu substrato na relação do sujeito com o objeto 
a. Portanto, para que se verifique o ato suicida como passagem ao ato, deve-se considerar tal objeto como central.

\section{A propensáo melancólica}

O respaldo para a abordagem da passagem ao ato é dado pelas proposiçóes acerca da angústia e do objeto $a$ introduzidas até então pelo autor em seu seminário. É desde aí que Lacan faz menção ao trabalho freudiano "A psicogênese de um caso de homossexualismo numa mulher" (Freud, 1920/1969), um caso de tentativa de suicídio.

No caso relatado por Freud (1920/1969), trata-se de uma jovem que desperta a atenção da família por manter certos galanteios e cortejos com uma dama de reputação questionável naquela sociedade. A jovem não se preocupava quanto a aparecer acompanhada da dama em ruas frequentadas de sua cidade. Certo dia, em companhia da dama, o pai passa pela mesma rua, o que não era evitado pela jovem, com olhar expressando ira. Da mesma feita, a dama se enraivece com a situação e rompe o caso que se dava entre as duas. Relata Freud (1920/1969, p. 160) que, "subitamente, a jovem saiu correndo e arremeteu-se em direção a um muro, saltando-o para o lado de um corte que dava para a linha ferroviária suburbana ali perto”. A tentativa de suicídio da Jovem Homossexual leva Freud a proferir algumas consideraçóes sobre o suicídio em que insiste na elucidação pela via da identificação ao objeto. A saber:

É provável que ninguém encontre a energia mental necessária para se matar, a menos que, em primeiro lugar, agindo assim, esteja ao mesmo tempo matando um objeto com quem se identificou e, em segundo lugar, voltando contra si próprio um desejo de morte antes dirigido contra outrem (Freud, 1920/1969, p. 174).

A queda da Jovem Homossexual é salientada por Lacan (1962-1963/2005) a partir do verbo utilizado por Freud (1920/1969), niederkommen. O verbo em questão indica tanto "dar à luz" quanto "vir abaixo", e é nesses termos que esse verbo "é essencial para qualquer relacionamento súbito do sujeito com o que ele é como $a "$ (Lacan, 1962-1963/2005, p. 124).

A queda do objeto $a$ e a relação disso com o sujeito levam Lacan (19621963/2005, p. 124) a afirmar: "Não é à toa que o sujeito melancólico tem tamanha propensão, e sempre realizada com rapidez fulgurante, desconcertante, a se 
atirar pela janela”. Embora no caso da Jovem Homossexual não se trate de um quadro de melancolia, a propensão melancólica ao ato suicida é aqui igualmente pensada nos termos da queda do objeto $a$. Lacan assinala que, na passagem ao ato, há uma saída de cena, saída muito bem demarcada pela precipitação através da janela. Assim, Lacan, ainda se valendo do caso da Jovem Homossexual, afirma que há duas condiçóes para que se realize a passagem ao ato:

A primeira é a identificaçấo absoluta do sujeito com o $a$ ao qual ele se reduz. É justamente o que sucede com a moça no momento do encontro. A segunda é o confronto do desejo com a lei. Aqui, trata-se do confronto do desejo pelo pai, sobre o qual se constrói toda a conduta dela, com a lei que se faz presente no olhar do pai. É através disso que ela se sente definitivamente identificada com o $a$ e, ao mesmo tempo, rejeitada, afastada, fora da cena. E isso, somente o abandonar-se, o deixar-se cair, pode realizar (Lacan, 1962-1963/2005, p. 125).

A identificação absoluta com o objeto $a$ é destacada como a evasão da cena. A saída de cena é caracterizada como o momento do embaraço maior do sujeito. O que se dá é a passagem da cena para o mundo. Tal distinção entre cena e mundo permite a Lacan (1962-1963/2005) destacar algo em relação à passagem ao ato. Ao propor, "de um lado, o mundo, o lugar onde o real se comprime, e, do outro lado, a cena do Outro, onde o homem como sujeito tem de se constituir" (Lacan, 1962-1963/2005, p. 130), a passagem ao ato é situada do lado do mundo, pois o que opera é uma saída da cena constituída pelo Outro. Há nesta evasão "um corte em que o historial dá um giro" (Harari, 1997, p. 81), um rompimento com o Outro como lugar de constituição do sujeito. Dessa forma, a passagem ao ato tem ressonância temporal ao fundar um corte em que aquilo que é da ordem da cena, ou do inconsciente, é rejeitado.

A formulaçáo que Lacan sustenta a respeito da passagem ao ato permite estabelecer uma distinção, relevante clinicamente, entre esta e o acting out. Segundo ele, "tudo o que é acting out é o oposto da passagem ao ato" (Lacan, 19621963/2005, p. 136). Em sua explanação acerca dessa oposição, Lacan se propõe a levar seus ouvintes pelas mãos, sem deixá-los cair. Essa já é uma indicação da oposição que se afirma, na medida em que a passagem ao ato se caracteriza por uma queda a partir da identificaçáo absoluta ao objeto. $\mathrm{O}$ acting out, por sua vez, é referido como uma mostração, uma entrada em cena (não uma saída). Algo é mostrado no acting out e isso é tomado por Lacan como algo que vem a dizer; o acting out clama por interpretação. 
Tanto em relação à passagem ao ato quanto ao acting out, o que se demonstra é que ambos possuem relação peculiar com o objeto $a$ e com a angústia. Enquanto o acting out é da ordem de um evitamento da angústia, sendo o objeto mostrado na montagem da cena dirigida ao Outro, na passagem ao ato a angústia passa ao ato na medida em que há a identificação absoluta com o objeto em jogo. No caso da passagem ao ato, Lacan lança mão da defenestração na melancolia para ilustrar seu modo de relação ao objeto $a$. Essa ilustração serve como guia para a questão aqui proposta da passagem ao ato suicida na melancolia: a queda do objeto $a$ é essencial para que se delimite a passagem ao ato na medida em que há uma identificação absoluta a esse objeto no momento da queda.

Com as consideraçóes feitas por Lacan acerca da tentativa de suicídio da Jovem Homossexual e com seu comentário sobre a propensão melancólica à defenestração pôde-se propor o suicídio na melancolia desde essa queda que arrasta o sujeito para fora da cena. Baseado no ensino do período de 1962-1963, é possível afirmar que o sujeito é trazido juntamente desse objeto caduco. É nesses termos que Lacan, ao término de seu seminário, em 3 de julho de 1963, faz a valiosa afirmação:

Na melancolia, trata-se de algo diferente do mecanismo de retorno da libido no luto e, por essa razão, todo o processo, toda a dialética se constrói de outra maneira. O objeto, Freud nos diz que é preciso - por que nesse caso? Deixo de lado a questáo - que o sujeito se entenda com ele. Mas o fato de se tratar de um objeto a e de, no quarto nível [escópico], este se encontrar habitualmente mascarado por trás da i(a) do narcisismo, atravesse sua própria imagem e primeiro a ataque, para poder atingir, lá dentro, o objeto a que o transcende, cujo mandamento lhe escapa - e cuja queda o arrasta para a precipitação suicida, com o automatismo, o mecanicismo, o caráter imperativo e intrinsecamente alienado com que vocês sabem que se cometem os suicídios de melancólicos (Lacan, 1962-1963/2005, p. 364).

Essa citação retoma a questão do suicídio na melancolia enquanto passagem ao ato. No exame que se realizou em "Sobre a psicopatologia da vida cotidiana” (Freud, 1901/1969) e em "Luto e melancolia” (Freud, 1917 [1915]/1969), destacou-se, em um primeiro momento, que o suicídio é reconhecido por Freud na mesma categoria que atos falhos e lapsos e, mais adiante, que a melancolia revela a identificação narcísica ao objeto e a submissão do eu ao castigo do supereu, acarretando o processo de automortificação do eu. A identificação referida resulta, então, na sobreposição da mencionada sombra do objeto ao eu melancólico. Com 
Lacan, como dissemos, é possível reinterrogar o suicídio em sua dimensão de ato com base na exploração freudiana da articulação entre suicídio e melancolia.

É dessa maneira que se destaca, a partir de Lacan, a distinçâo do processo melancólico em relação ao luto, afirmando a participaçáo do objeto $a$, que, no nível escópico dos diferentes estágios desse objeto, se oculta na imagem real constituidora do eu na especularização. Nesses termos, a base narcísica para o processo melancólico é mantida pelo autor. Além disso, segundo Lacan, "é o objeto que triunfa" (Lacan, 1962-1963/2005, p. 364) e isto está completamente de acordo com as afirmaçóes de Freud (1917 [1915]/1969) sobre o abandono dos atributos do objeto e o império do não-assimilável sobre o eu melancólico. A proposição freudiana de que esse processo acontece fora do âmbito das palavras e representações, estando barrado, inacessível, é destacada por Lacan como a mais radical relação com o objeto $a$, "intrinsecamente desconhecida, alienada, na relação narcísica” (Lacan, 1962-1963/2005, p. 364). Para que haja o ato suicida é necessária a passagem, o movimento para que o sujeito totalmente identificado ao objeto $a$ acompanhe-o em sua precipitação. Desta feita, com toda a certeza provida pela angústia anterior à cessão, o suicídio na melancolia pode ser pensado enquanto passagem ao ato.

\section{Consideraçóes finais}

Em seu seminário proferido no período de 1962-1963, Lacan ocupou-se do tema da angústia e estabeleceu a mesma, como vimos, enquanto eixo para pensar o objeto $a$ em relação à passagem ao ato. Por isso, seguiu-se nesse artigo seu percurso referente ao objeto $a$ no seminário, tendo em vista as consideraçóes acerca da passagem ao ato suicida na melancolia. Desse modo, tomamos o ensino de Lacan, nessa etapa, como tendo assumido os termos do problema que Freud estabeleceu ao investigar o suicídio à luz da melancolia. Se, em um primeiro momento, Freud interrogou o lugar do eu no que concerne à autodestruição, o recurso a um elemento sádico que estaria aí em jogo incluiu na discussão a problemática do objeto. Nesse contexto, contudo, o autor dissecou o objeto com uma tal agudeza que as particularidades do modo como este opera na lógica construída em torno da melancolia (e do tema do suicídio a ela articulado) ensejam a pergunta acerca de seu estatuto. O desdobramento do objeto $a$ em Lacan foi tomado, no artigo, em resposta a tal pergunta emergida do texto freudiano, bem como possibilitou reaver a questáo do suicídio em sua dimensão de ato, o que, em Freud, restara como uma menção no início de sua obra. 
Como condição primeira para a passagem ao ato, para a evasão da cena, Lacan destacou a identificação total ao objeto $a$. Deu-se, nesse artigo, destaque a essa primeira condição, visto ser ela que permite estabelecer uma retomada das proposições freudianas referentes à identificação narcísica e ao império da sombra do objeto sobre o eu melancólico. Retomando o caso da Jovem Homossexual, Lacan destacou, como vimos, o verbo niederkommem como essencial para qualquer relacionamento súbito do sujeito com o que ele é como $a$. $\mathrm{O}$ deixar-se cair, contido no verbo em destaque, indica a identificação absoluta ao objeto. A partir disso, Lacan afirmou não ser à toa haver uma propensão melancólica em se atirar pela janela (1962-1963/2005, p. 124). Desde essa ponderação feita por Lacan, foi possível questionar o ato suicida na melancolia em termos da queda do objeto $a$. Foi dessa forma que se acompanhou o ensino de Lacan, em 1962-1963, tendo como foco esse objeto que, em sua queda, arrasta o sujeito. A queda do objeto $a$ na passagem ao ato é destacada por Brodsky (2004, p. 74) como "rechaço do inconsciente" que encontra no suicídio sua maior expressão na medida em que o êxito demarca uma ruptura definitiva com a cena do Outro.

A queda do objeto arrasta consigo, para fora da cena do Outro, o sujeito quando totalmente identificado. É como um suicídio do objeto, o qual desaparece do campo do desejo, que se define aqui o ato disruptivo. $\mathrm{O}$ ataque e atravessamento de i(a) permite a identificação absoluta ao objeto em questão. Também é necessário o acréscimo do movimento, da moção, para que se efetue a passagem ao ato. A certeza provinda da angústia anterior à cessão do objeto é passada ao ato, e, nesse percurso, o sujeito acompanha seu objeto que não pode ser cedido. No mais radical rompimento em relação ao significante, já indicado por Freud (1917 [1915]/1969) quando afirma que o processo melancólico no qual triunfa o objeto acontece fora do âmbito das palavras, o suicídio na melancolia pode ser tomado como passagem ao ato na medida em que se sustenta o impasse simbólico que permeia qualquer consideração acerca da melancolia.

Muitos pontos do percurso traçado nesse artigo necessitariam de maior aprofundamento. A questão não se encerra por conta do panorama que se abre no sentido da discussão empreendida aqui. O objetivo de sustentar a proposição do suicídio na melancolia enquanto passagem ao ato, baseado em trabalhos específicos de Freud e de Lacan, é tão somente a sustentação de uma questão que envolve uma via de reflexão em que muito escapa ao alcance do percurso recortado. Por exemplo, é uma interrogação se o suicídio, independentemente da estrutura em jogo, poderia ser tomado a partir de um paradigma melancólico em vista da iden- 
tificação absoluta ao objeto $a$, como fundamento primeiro da passagem ao ato, e da identificação narcísica destacada por Freud (1917 [1915]/1969), referente ao desencadeamento do processo melancólico.

A referência lacaniana aqui seguida permitiu destacar a presença fulgurante do objeto $a$ no momento da passagem ao ato suicida na melancolia. Dessa presença são correlatas a ausência de um sujeito - o qual é apagado ao máximo pela barra - e a ruptura mais radical em relação ao Outro. Desde este instante peculiar "compreende-se, portanto, a dificuldade do sujeito ao falar no só-depois de seu ato: ele alterou-se, não é mais o mesmo, e aliás, no momento do ato, ele ali não era" (Morel, 2002, p. 12). Considerando o ato em sua função de corte e giro histórico que instala um antes e um depois, é possível perguntar se, já que no instante do ato o sujeito é ausente, o Outro pode ser interrogado em seu horizonte, no depois. Sobre o Outro em sua relação ao ato, Brodsky (2004, p. 17) indica que "o Outro sempre acompanha a dimensão do ato, precisamente para que se vá além dele", tornando assim digna de indagação a coordenada significante do ato mesmo que no exato momento deste haja o triunfo do abjeto $a$.

São perspectivas que se abrem a partir do Seminário - livro 10, a angústia (1962-1963/2005) e que teráo ocasiáo de serem abordadas por Lacan em trabalhos posteriores a este. Desde aí, coloca-se em questão a possibilidade de uma abordagem do suicídio pela psicanálise, ou melhor: que clínica se faz do ato? Isso porque, no momento da passagem ao ato suicida, há o inefável comparecimento do objeto a com o qual, segundo o cálculo lacaniano, não se opera. No entanto, como se trata de um momento, pode-se interrogar o que precede e, quando possível, o que sucede se este ato falhar.

\section{Referências}

Brodsky, G. (2004). Short story - os princípios do ato analítico. Rio de Janeiro: Contra Capa. Charliac, L. (2002). Causes et contingence d'une tentative de suicide. In G. Morel (Org.). Clinique du suicide (pp. 209-217). Ramonville Saint-Agne: Érès.

Freud, S. (1969). Sobre a psicopatologia da vida cotidiana. In S. Freud, Edição standard brasileira das obras psicológicas completas de Sigmund Freud, v. VI. Rio de Janeiro: Imago. (Trabalho original publicado em 1901)

Freud, S. (1969). Breves escritos: contribuiçôes para uma discussão acerca do suicídio. In S. Freud, Ediçäo standard brasileira das obras psicológicas completas de Sigmund Freud, v. XI. Rio de Janeiro: Imago. (Trabalho original publicado em 1910) 
Freud, S. (1969). Luto e melancolia. In S. Freud, Edição standard brasileira das obras psicológicas completas de Sigmund Freud, v. XIV. Rio de Janeiro: Imago. (Trabalho original publicado em 1917 e escrito em 1915)

Freud, S. (1969). A psicogênese de um caso de homossexualismo numa mulher. In S. Freud, Edição standard brasileira das obras psicológicas completas de Sigmund Freud, v. XVIII. Rio de Janeiro: Imago. (Trabalho original publicado em 1920)

Freud, S. (1969). O ego e o id. In S. Freud, Edição standard brasileira das obras psicológicas completas de Sigmund Freud, v. XIX. Rio de Janeiro: Imago. (Trabalho original publicado em 1923)

Harari, R. (1997). O seminário "a angústia" de Lacan: uma introdução. Porto Alegre: Artes e ofícios.

Lacan, J. (2005). O seminário, livro 10: a angústia. Rio de Janeiro: Jorge Zahar. (Trabalho original de 1962-1963)

Lambotte, M.-C. (2000). Estética da melancolia. Rio de Janeiro: Companhia de Freud.

Morel, G. (2002). Actes réussis, actes ratés: lectures psychanalytiques du suicide. In G. Morel (org.). Clinique du suicide (pp. 09-16). Ramonville Saint-Agne: Érès.

Quinet, A. (2006). Psicose e laço social. Rio de Janeiro: Jorge Zahar.

\section{Nota}

${ }^{1}$ Este artigo é derivado da dissertação de mestrado "A sombra do objeto: um percurso entre a melancolia e a passagem ao ato", defendida pelo aluno Marcos Vinicius Brunhari (Bolsista CAPES-Reuni) em abril de 2010, no Programa de Pós-Graduação - Mestrado em Psicologia da Universidade Federal do Paraná (UFPR), sob orientação do Professor Doutor Vinicius Anciães Darriba.

Recebido em 20 de junho de 2012 Aceito para publicação em 14 de março de 2013 